\title{
Application of solar photovoltaic generation in the world
}

\author{
Zheng Hongxia ${ }^{1}$, Tian Yuqing ${ }^{2}$ and Chen Deying ${ }^{1}$ \\ ${ }^{1}$ Training Center of State Grid Jiangxi Electric Power Company, Nanchang, 330000, China \\ ${ }^{2}$ Education and Evaluation Center of Yunnan Power Grid Corporation, Kunming, 650000, China
}

\begin{abstract}
Recent years,the rapid development of solar photovoltaic has become a new hope to save the environment pollution and resource shortage in the electric power era.Countries have introduced relevant policies to support the development of photovoltaic power generation industry actively. Independent household solar photovoltaic system and Large-scale photovoltaic grid-connected system have been used successfully.However,development of countries' photovoltaic inductry is uneven due to synchronized technology and resources. This paper describes the status quo of $\mathrm{PV}$ industry in major PV application countries.
\end{abstract}

\section{Introduction}

Energy is the basic of social development.Since the industrial revolution,we have experienced steam age and electrical age.Every change is accompanied with a change in the pattern of energy and marks great progress of human civilization.In the last centuries, electricity is the basis of global social and economic development accompanied with the improvement of industrialization and energy application.During this period,mining non-renewable resources and consuming fossil energy continuously leads to resource tension,air pollution,greenhouse effect,climate change and so on.Primary energy consumption is mainly concentrated in Asia Pacific,European continent,North America.As of 2013, Coal production in the Asia-Pacific region accounts for $26.7 \%$ of global coal production,but its coal use accounts for $68.8 \%$ of global consumption;Europe and the Eurasian coal production accounted for $42.4 \%$ of global coal production, but its coal use accounts for only $11.6 \%$ of global consumption. The origin and consumption areas of coal is seriously uncoordinated as traditional power production materials, therefore, the exploition and transportation of coal may pollutes environmental.Indeed, the gap between fossil fuel reserves has caused disputes in the Middle East countries.Energy application model is changing which is aimed at reducing the impact of fossil energy on human beings.Clean energy substitution and electric energy substitution is the core of energy consumption patterns transformation.At present, wind power and photovoltaic power is the most widely used cleaning power.Wind power is limited by its geographical distribution of resources.Solar photovoltaic has such features as simple installation,small floor area,noise free,individual household or photovoltaic grid-connected,and that it has been popularized widely[1-3].Photovoltaic power generation will become the mainstream.

\section{Distribution of global solar radiation}

The distribution of solar energy resource is evidently regional which is affected by climate.Solar radiation in North Africa,Middle East,Southwestern United States,Mexico,Southern Europe,Australia, South Africa and Western China is strongest.The solar energy in the areas is best both duration and intensity of sunlight so these areas have a unique advantage in using solar power.Total solar radiation(year) in some areas was shown in Table 1.The solar radiation in North Africa and part of American is the most abundant.The distribution of solar radiation in these areas is not significant as Southern Europe,the Middle East,Australia and China.The following application of the current situation is based on Table 1 whose solar radiation is abundant.Photovoltaic power generation of countries in the areas is not all going well although those solar radiation is abundant.

\section{Applicatin of solar photovoltaic generation}

Photovoltaic power generation includes independent photovoltaic system and photovoltaic grid connected system according to whether the grid is connected to the 
Table 1. Total solar radiation(year) in major countries

\begin{tabular}{|c|c|c|}
\hline $\begin{array}{c}\text { country } \\
\text { Radition and area }\end{array}$ & Total solar radiation(year)/ $\left(\mathrm{MJ} / \mathrm{m}^{2}\right)$ & distribution area \\
\hline Algeria & 9720 & \\
\hline Morocco & 9360 & \\
\hline $\begin{array}{l}\text { Tunisia } \\
\text { Libya }\end{array}$ & $>8280$ & \\
\hline Spain & 8100 & \\
\hline Italy & 7200 & \\
\hline Greece & 6840 & \\
\hline Portugal & 7560 & \\
\hline $\begin{array}{c}\text { Israel } \\
\text { Jordan } \\
\text { Saudi Arabia }\end{array}$ & 8640 & \\
\hline $\begin{array}{l}\text { United Arab } \\
\text { Emirates, Iran }\end{array}$ & 7920 & \\
\hline \multirow{3}{*}{ United States } & $9198-10512$ & First area $(9.36 \%$ of US area $)$ \\
\hline & 7884-9198 & Second area $(35.67 \%$ of US area) \\
\hline & $6570-7884$ & Third area $(41.48 \%$ of US area $)$ \\
\hline China[4] & $6680-8400$ & Western China \\
\hline \multirow{2}{*}{ Australia } & $7621-8672$ & First area $(54.18 \%$ of Australia's area $)$ \\
\hline & $6570-7621$ & Second area( $35.44 \%$ of Australia's area) \\
\hline
\end{tabular}

grid.Independent photovoltaic includes photovoltaic system with storage battery and photovoltaic system without storage battery.The cost of solar photovoltaic generation system is composed of solar panels,inverters, batteries, post-maintenance costs. The cost of solar photovoltaic generation is much higher than traditional power generation system which is counted base on the life of solar panel.Although photovoltaic grid connected technology has been put into application, it is still in the early stages of development and the technology is immature.Countries have introduced relevant supporting policies, however,the support gradually weakened in recent years.In addition,government support is not a permanent solution, because each photovoltaic system has its service life.

Factors that restricted photovoltaic power generation industry development are as follows:

-The main raw material for solar cell silicon crystal is scarce in prophase.

-The conversion efficiency of solar panel sold on market is low as the coversion efficiency of mainstream monocrystalline silicon cell and polycrystalline silicon cell $15 \%-21 \%$ and the coversion efficiency of thin-film solar battery is just $6 \%-13 \%$, the differences of solar cells sold on market is shown in Table 2.

-The development of solar cell manufacturing technology is uneven, the production technology is not shared.

-Photovoltaic power generation has a typical periodic,but storage battery can not achieve a large number of energy storage. 
Table 2. Comparison of photovoltaic cells

\begin{tabular}{|c|l|l|l|}
\hline $\begin{array}{c}\text { Performance } \\
\text { Types of solar cell }\end{array}$ & $\begin{array}{l}\text { Monocrystalline silicon } \\
\text { cell }\end{array}$ & Polycrystalline silicon cell & \multicolumn{1}{|c|}{ Thin film solar cell } \\
\hline $\begin{array}{c}\text { photoelectric conversion } \\
\text { efficiency }\end{array}$ & \multicolumn{1}{|c|}{$15 \%-21 \%$} & $15 \%-18 \%$ & $\begin{array}{l}6 \%-13 \% \text { (The cell can still work } \\
\text { with weak light.) }\end{array}$ \\
\hline manufacturing cost & $\begin{array}{l}\text { The production cost is } \\
\text { high, and can not be } \\
\text { widely applied at present }\end{array}$ & $\begin{array}{l}\text { Mass production can be } \\
\text { carried out due to its low } \\
\text { production cost with simple } \\
\text { manufacturing process and } \\
\text { low power consumption. }\end{array}$ & $\begin{array}{l}\text { The production process is } \\
\text { completely different from the } \\
\text { crystal silicon battery, the process } \\
\text { greatly simplified, the silicon } \\
\text { material consumption is low, and } \\
\text { the power consumption is low }\end{array}$ \\
\hline Service life & $\begin{array}{l}\text { It is packaged by } \\
\text { toughened glass and } \\
\text { waterproof resin.Its } \\
\text { service life is about } \\
15-25 \text { years }\end{array}$ & $\begin{array}{l}\text { It is packaged by EVA.Its } \\
\text { service life is shorter than } \\
\text { Monocrystalline silicon } \\
\text { cell. }\end{array}$ & $\begin{array}{l}\text { About 10 years.Its conversion } \\
\text { efficiency decreases obviously } \\
\text { with time. }\end{array}$ \\
\hline
\end{tabular}

Photovoltaic cells on market is less redundant because the longer the time,the lower the efficiency is.Polysilicon is the main raw material for photovoltaic panels. We can get it that polysilicon industry is glut base on the data during 2010-2015.It reflects the supply of raw materials for photovoltaic cells is sufficient, while the production technology is not advanced.

\subsection{Application of photovoltaic power generation in USA}

United States has introduced a new bill which is aimed at solving the problem that new energy enterprise is lacking motivation in developing new technologies.New energy plan and harsh environmental requirements for fossil fuels are presented.The plan proposed that goverment will offer capital and technology to photovoltaic power generation industry by subsidizing raw material procurement and production[5].Renewable Energy Power Generation Tax Credit Policy (PTC) has been extended to 2020 and Federal Commercial Energy Investment Tax Credit Policy (ITC) has been extended to 2022. New gross capacity of photovoltaic power generation in United States is $7.286 \mathrm{GW}$ in 2015 . The number is $14.726 \mathrm{GW}$ in 2016.PV installed capacity accounted for $39 \%$ in the whole year in 2016. The accumulated photovoltaic power installed capacity of American is $25 \mathrm{GW}$ by 2015.

\subsection{Application of photovoltaic power generation in Germany}

Germany is undoubtedly the leader in the photovoltaic industry.Germany demands the most in Europe market demand for photovoltaic power generation products which is benefited from that German government is forward-looking in terms of new energy inductry and advanced industrial system and semiconductor technology.It has obvious advantage in photovoltaic inductry due to its key production technology and production technics.German government revises the German renewable energy law continuously to make it better serve the photovoltaic industry in according to domestic and international economic environment[6].The goverment has provided cridit to feed-in-tariffs.Germany has a lot of home photovoltaic power generation system, which gave birth to the development of household energy storage market.More and more industries are participating in this market.The accumulated photovoltaic power installed capacity of Germany is $39.40 \mathrm{GW}$ by 2015.

\subsection{Application of photovoltaic power generation in Japan}

Japan is a country that is less dense and lacks natural resources.Japan is one of the countries that started the photovoltaic industry earlier.Japan has re-planned its energy development structure after Fukushima nuclear meltdowns.Subsequently,it introduced a 10-year bill in regard to renewable energy subsidies[7].The bill aims to promote the development of photovoltaic power generation industry.However,solar companies appear bankruptcy peak in Japan due to government support policy tightening and poor management.So the future of Japan's PV development trend is still unknown

\subsection{Application of photovoltaic power generation in China}

China's photovoltaic manufacturing production plays original equipment manufacturer in global.Failed to grasp key production technology and production technics of photovoltaic industry contributed its passive position.In view of environmental problems such as resource shortage and severe haze, China has introduced a series of supporting policies of which the core is subsidizing photovoltaic power generation equipment installation and feed-in tariffs. The pre-subsidy policy only takes into account the installed capacity without taking into account the power generation. The electricity price subsidies is reducing gradually in order to reduce the dependence of the photovoltaic industry on the policy.Industrial 
development focus from the previous expansion of the scale of development to improve efficiency and prrofit[8-10].The accumulated photovoltaic power installed capacity of China is $43 \mathrm{GW}$ by 2015 .

\section{Development direction of photovoltaic power generation}

The count shows that global power demand showed a sustained growth and areas have a shortage of electricity.Electricity is not enough to rely on traditional electricity generation, the shortage must be supplied by renewable energy power generation.Solar photovoltaic generation is bound to be the main power supply form in the future due to its innate advantages. The main factors that limit the large-scale application of photovoltaic power generation are:

-Long-term effective encouraging policies and unified planning is lacking.

-There is no uniform technical standards.

-The construction cost of photovoltaic power generation system is high.

-Conversion efficiency of photovoltaic power generation inverter is low.

-Post-maintenance costs are high and maintenance-related statutes are immature[11-12].

\section{Conclusion}

Solar radiation on earth is renewable and ample.Solar photovoltatic will certainly be a major player because of its simple installation,small floor area and noise free.Photovoltaic power generation has been applied in many countries in the past decades.Independent household photovoltaic power generation system can solve the problem of power supply in remote area effectively and large-scale photovoltaic grid-connected system can effectively alleviate the shortage of power supply and environmental pollution.However,PV industry still has a series of problems in terms of policy and technology, such as high production cost of power generation system,low conversion efficiency of photovoltaic inverter, grid fluctuation caused by grid connection,large amount of electric energy storage etc.At present,regardless of which country, its rapid development of photovoltaic power generation scale and policy support are closely tied.And then, what we have to do is reducing the installation cost,generation cost and maintenance cost of photovoltaic generation.It's no longer a dream that solar photovoltaic generation become the dominant as science and technology is developing.

\section{References}

1. Lv Bei,Qiu Hemei,Zhang Yu.Present Status and Development of Solar Photovoltaic Power Generation Industry [J].Huadian Technology,2010,01:73-76+82.

2. Wang Yimin.Concept and Prospects of Global Energy Internet [J].China Electric Power,2016,03:1-5+11.

3. Liu Zhenya.Study and Prospect of Global Energy Internet between country and between continental [J].Proceeding of CSEE,2016,19:5103-5110+5391.

4. Zhu Weigang,Lin Yanmei,Zhou Lei.Application of Solar Photovoltaic Power Peneration in China [J].Modern electric power,2007,05:19-23.

5. Xiao Li.Study on The International Competitiveness of Chinese Photovoltaic Industry [D].Hainan University, 2016.

6. Kong Xiangxin.Study of Photovoltaic Industry Trade Conflict between China and Europe and United States [D].Shandong Normal University,2014.

7. Liu Qingrong,Gu Qunyin,Ruan Yingjun,Ren Jianxing,Long Youer,Gao Weijun .Policy and Example of Japanese Solar Photovoltaic Power Generation System [J].East China Electric Power,2009,02:279-283.

8. Wang Sicheng, Wu Dacheng. Review and Prospect of photovoltaic policy in China (Part I) [J]. Solar Energy, 2016,06: 19-24+39.

9. Wang Sicheng, Wu Dacheng, Review and Prospect of photovoltaic policy in China (Part II) [J]. Solar Energy, 2016, 07: 5-11.

10. Zhang Pengchao. Research on incentive policy of PV industry in China [D]. North China Electric Power University, 2015.

11. Shao Riming,Mary KAYE,Chris DIDUCH, Zhang Liuchen. Basic function components of distributed photovoltaic inverters in smart grid [J]. Proceedings of the Chinese society of electrical engineering, 2013, 34: $83-90+15$.

12. Lu Meiling, Zhang Geng, Liu Song, Lv Lei. Optimal scheduling model for economic benefit of home photovoltaic power generation system based on energy Internet $[\mathrm{J}]$. Power System and Automation, 2016, S1: 141-146. 